\title{
Development Proposal of FECV Based on Life Cycle Cost
}

\author{
Yun Cai ${ }^{1,2} *$, Yiqiang Peng ${ }^{1}$, Mengnan Guo ${ }^{2}$, Zongling Huang ${ }^{2}$, Shengming Han ${ }^{2}$, Xue Luo ${ }^{2}$ \\ 1 School of Automobile and Transportation, Xihua University, Chengdu 610039 China \\ 2 Chengdu Automobile Industry Research Institute, Chengdu 610100 China \\ *e-mail 29682131@qq.com
}

\begin{abstract}
FECV was one of the important technical routes of China's new energy vehicle industry. Combining with the whole life cycle cost, the paper offers the development measures and suggestions of Sichuan FECV industry. Based on the component factors of the whole life cycle cost, the advantages and disadvantages of traditional fuel vehicles, pure electric vehicles and hydrogen fuel cell vehicles are compared and analyzed from the three dimensions of $R \& D$ and design cost, product manufacturing cost and use cost. The shortcomings of hydrogen fuel cell vehicles in the research, development, manufacturing and application at the present stage were concluded. The paper puts forward three development proposals, demonstration application, basic supporting and policy support to reduce the comprehensive use cost of hydrogen fuel cell vehicles, so as to strengthen and expand the hydrogen fuel cell vehicle industry in Sichuan Province.
\end{abstract}

Keywords-FECV, life cycle cost, comprehensive cost comparison, development suggestions

\section{INTRODUCTION}

According to the technical roadmap of energy-saving and new energy vehicles and the documents of the Ministry of industry and information technology, new energy vehicles refer to the vehicles that use unconventional vehicle fuel as the power source (or use conventional vehicle fuel, use new vehicle power device), integrate the advanced technology of vehicle power control and drive, and form the vehicles with advanced technical principle, new technology and new structure. New energy vehicles include hybrid electric vehicles, pure electric vehicles (Bev, including solar vehicles), fuel cell electric vehicles (FCEV), hydrogen engine vehicles, other new energy vehicles (such as efficient energy storage devices, dimethyl ether) and other categories of products. FECV is an important technical route in China's new energy vehicle industry[1]. In recent years, FECV industry has developed rapidly. This paper makes a comparative analysis of FECVs and other types of vehicle products from the perspective of the whole life cycle, and puts forward targeted measures and suggestions.

\section{CONNOTATION OF FECV}

FECV refers to the vehicle-mounted hydrogen as the energy source, through the proton exchange membrane fuel cell

Fund projects: Chengdu Science and technology project (2019-RK0000025-ZF), Sichuan Science and technology support plan project (2016GZ0017), Sichuan University Key Laboratory Project of Automotive Engineering (szjjj2014-072). Sichuan Science and Technology Program (2019JDR0076) to convert the chemical energy of hydrogen into electrical energy, motor-driven vehicle[2], excluding the vehicle with fossil fuel as the fuel and hydrogen produced by the vehiclemounted device as the energy source.

FECV industry is the most potential application scenario that can rapidly promote the development of hydrogen energy industry. In recent years, with the continuous maturity of FECV technology, at the same time, FECVs can effectively solve many pain points such as long charging time, short endurance mileage, and difficult power battery recovery of pure electric vehicles. It is expected that FECVs will usher in a period of development opportunity of "Big Bang" in the future.

From the perspective of policy, technology and market, it is the general trend to promote the development of hydrogen fuel cell automobile industry in the world. At the policy level, the United States, Japan, Europe, South Korea, China and other major countries and regions in the world will increase the development of FECVs to a national strategic height. At the technical level, foreign hydrogen fuel cell passenger vehicles and commercial vehicles are stepping into industrialization; domestic hydrogen fuel cell commercial vehicles are stepping into industrialization, and the introduction of hydrogen fuel cell passenger vehicles is accelerating. At the market level, by the end of 2018, there are more than 8000 passenger cars sold in the world, and nearly 2000 FECVs sold in China. Therefore, in the next few years, the FECV industry is bound to rise rapidly and become an important part of new energy vehicles.

\section{COMPARISON OF FULl LIFE CYClE COST}

In the promotion and use of FECVs, it is inevitable to compete with traditional fuel vehicles and pure electric vehicles. If the industry can get express delivery, it must be recognized by the end consumer market[3]. In addition to the technical aspect, the comprehensive cost of the product should be superior to or close to other automotive products.

Life cycle cost (LCC)[4] refers to all costs related to the product during the effective use period, including product design cost, manufacturing cost, procurement cost, use cost, maintenance cost, waste disposal cost, etc.[5]. In order to facilitate comparison, the comprehensive cost of the whole life cycle automotive products in this paper mainly considers the $\mathrm{R}$ $\& \mathrm{D}$ design cost, product manufacturing cost and later use cost (including maintenance cost). 
manufacturing costs of power systems (engine + transmission) and automobile electronic systems account for $55 \%$ of the total production and manufacturing costs of traditional fuel vehicles; batteries, The total manufacturing costs of electric motor and electric control account for 55\% of the total of pure electric new energy vehicles.

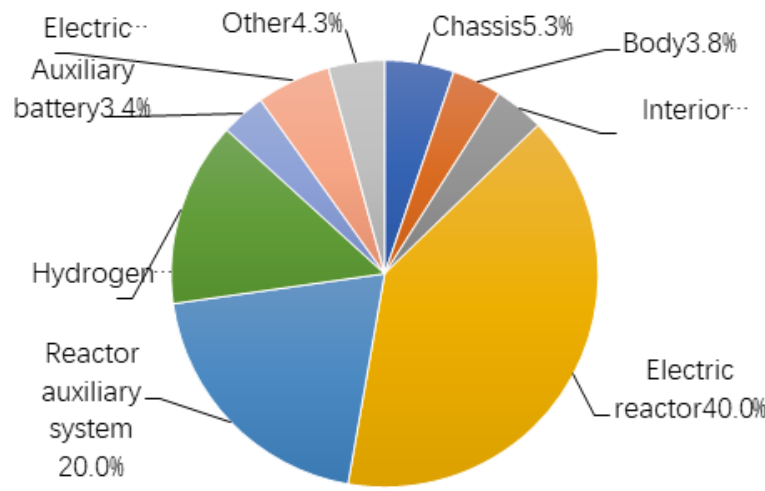

Fig.1. Cost composition of FECV (the electrical system. Compared with traditional fuel vehicles, new energy vehicles are currently common in chassis and body (interior), but there is a big difference between the power system and electronic control.

FECVs and pure electric vehicles are all new energy vehicles. The two are quite different in the battery part. The former uses the hydrogen-oxygen ion chemical reaction to generate electricity, the latter uses the stored electricity; the former hydrogenate (the filling time) 3-5 minutes), the latter is charged (5-8 hours). The power system part, in which the FECV is a fuel cell engine system (pile, sub-system, hydrogen storage bottle, auxiliary battery), motor, etc.; pure electric new energy vehicle is a "three-electric" system (battery, motor, Electronic control).

The comparative analysis of the components of the three types of vehicle products of traditional fuel vehicles, FECVs and pure electric vehicles is shown in the following Table I.

TABLE I. COMPONENT OF FECVS, TRADITIONAL FUEL VEHICLES AND PURE ELECTRIC VEHICLES

\begin{tabular}{|c|c|c|}
\hline $\begin{array}{c}\text { Components of hydrogen } \\
\text { fuel vehicle }\end{array}$ & $\begin{array}{c}\text { Components of } \\
\text { traditional fuel } \\
\text { vehicles }\end{array}$ & $\begin{array}{c}\text { Components of } \\
\text { pure electric } \\
\text { vehicle }\end{array}$ \\
\hline \multicolumn{3}{|c|}{ Chassis } \\
\hline $\begin{array}{c}\text { Fuel cell engine (electric } \\
\text { reactor, sub-system, hydrogen } \\
\text { storage bottle, auxiliary } \\
\text { battery) }\end{array}$ & $\begin{array}{c}\text { Power system } \\
\text { (Engine } \\
\text { +Transmission) }\end{array}$ & $\begin{array}{c}\text { Electric machinery } \\
\text { Electronic control }\end{array}$ \\
\hline $\begin{array}{c}\text { Electric machinery } \\
\text { Electronic control }\end{array}$ & Electrical System \\
\hline \multicolumn{2}{|c|}{ Others } \\
\hline
\end{tabular}

In the manufacturing costs of FECVs, traditional fuel vehicles and pure electric new energy vehicles, the total production and manufacturing costs of stacks, stack auxiliary systems, hydrogen storage bottles, auxiliary batteries and motors account for $83 \%$ of the total production and manufacturing costs of FECVs; the total production and
TABLE II. COMPARATIVE ANALYSIS OF MANUFACTURING COST OF COMPONENTS OF FECVS, TRADITIONAL FUEL VEHICLES AND PURE ELECTRIC VEHICLES

\begin{tabular}{|c|c|c|c|c|c|}
\hline \multicolumn{2}{|c|}{ Hydrogen fuel vehicle } & \multicolumn{2}{|c|}{$\begin{array}{c}\text { Conventional fuel } \\
\text { vehicle }\end{array}$} & \multicolumn{2}{|c|}{ Pure electric car } \\
\hline Part Name & $\begin{array}{c}\text { Value } \\
\text { share /\% }\end{array}$ & Part Name & $\begin{array}{c}\text { Value } \\
\text { share } \\
/ \%\end{array}$ & $\begin{array}{c}\text { Part } \\
\text { Name }\end{array}$ & $\begin{array}{c}\text { Value } \\
\text { share } \\
/ \%\end{array}$ \\
\hline Chassis & 5.3 & Chassis & 10 & Chassis & 14 \\
\hline Body & 3.8 & Body & 15 & Body & 10 \\
\hline $\begin{array}{l}\text { Interior and } \\
\text { exterior } \\
\text { decoration }\end{array}$ & 3.8 & $\begin{array}{l}\text { Interior and } \\
\text { exterior } \\
\text { decoration }\end{array}$ & 10 & $\begin{array}{c}\text { Interior } \\
\text { and } \\
\text { exterior } \\
\text { decoration }\end{array}$ & 10 \\
\hline $\begin{array}{l}\text { Electric } \\
\text { reactor }\end{array}$ & 40 & \multirow{3}{*}{$\begin{array}{c}\text { Power } \\
\text { system } \\
\text { (engine }+ \\
\text { transmission) }\end{array}$} & \multirow{3}{*}{21} & Battery & 30 \\
\hline $\begin{array}{l}\text { Reactor } \\
\text { auxiliary } \\
\text { system }\end{array}$ & 20 & & & Electric & \multirow{2}{*}{10} \\
\hline $\begin{array}{l}\text { Hydrogen } \\
\text { storage } \\
\text { bottle } \\
\end{array}$ & 14 & & & machinery & \\
\hline $\begin{array}{c}\text { Auxiliary } \\
\text { battery }\end{array}$ & 3.4 & \multirow{2}{*}{$\begin{array}{l}\text { Automotive } \\
\text { electronic } \\
\text { system }\end{array}$} & \multirow{2}{*}{34} & \multirow{2}{*}{$\begin{array}{c}\text { Electronic } \\
\text { control }\end{array}$} & \multirow{2}{*}{15} \\
\hline $\begin{array}{c}\text { Electric } \\
\text { machinery }\end{array}$ & 5.6 & & & & \\
\hline Others & 4.3 & Other & 10 & Other & 11 \\
\hline
\end{tabular}

In terms of purchase cost, FECVs, traditional fuel vehicles and pure electric vehicles have the highest cost at this stage, followed by pure electric vehicles, and traditional fuel vehicles.

From the perspective of energy consumption, in the case of similar models of FECVs, traditional fuel vehicles and pure electric vehicles, the fuel consumption of traditional fuel

\section{Comparison of use cost}


vehicles is about 8 liters per $100 \mathrm{~km}$, and the fuel cost is 64 yuan; the power consumption of pure electric new energy vehicles is about 16 degrees per $100 \mathrm{~km}$, and the power cost is about 20 yuan; the hydrogen consumption of FECVs is $1 \mathrm{~kg}$ per $100 \mathrm{~km}$, and the hydrogenation cost is about 20-30 yuan. At present, the fuel cost of traditional fuel vehicles is the highest, and FECVs and pure electric vehicles are similar.
In terms of maintenance, FECVs, traditional fuel vehicles and pure electric vehicles have the same models. At present, the cost of FECVs is the highest, pure electric vehicles are the second, and traditional fuel vehicles are the lowest.

TABLE III. COMPARATIVE ANALYSIS OF THE USE COST OF FECVS, TRADITIONAL FUEL VEHICLES AND PURE ELECTRIC VEHICLES

\begin{tabular}{|c|c|c|c|c|c|}
\hline Energy type & Hydrogen & Energy type & Gasoline & Energy type & Electricity \\
\hline Energy consumption per $100 \mathrm{~km}$ & $1 \mathrm{~kg}$ & Energy consumption per $100 \mathrm{~km}$ & $8 \mathrm{~L}$ & Energy consumption per $100 \mathrm{~km}$ & $16 \mathrm{kWh}$ \\
\hline Energy price & 22 30yuan/kg & Energy price & 8yuan/L & $\begin{array}{l}\text { Energy price } \\
\end{array}$ & 1.3yuan $/ \mathrm{kWh}$ \\
\hline Energy cost per $100 \mathrm{~km}$ & 22 30yuan & Energy cost per $100 \mathrm{~km}$ & 64yuan & Energy cost per $100 \mathrm{~km}$ & 20yuan \\
\hline
\end{tabular}

\section{Comparison of comprehensive cost}

By comparing the $\mathrm{R} \& \mathrm{D}$, design, manufacturing and use costs of FECVs, traditional fuel vehicles and pure electric new energy vehicles[6], we can see that: First, the R \& D and design cost of FECVs is higher than that of traditional fuel vehicles and pure electric new energy vehicles. Second, the production and manufacturing cost of hydrogen fuel cell is far higher than that of traditional fuel vehicles and higher than that of pure electric new energy vehicles. Third, the use cost of FECVs is low, which is the same as that of pure electric vehicles, $65 \%$ lower than that of traditional fuel vehicles.

\section{SugGESTIONS FOR THE DEVELOPMENT OF FECVS IN SiCHUAN PROVINCE BASED ON LIFE CyCLE COST}

Through the comparative analysis of the whole life cycle cost, in order to achieve rapid development of Sichuan hydrogen fuel cell automobile industry[7], it is necessary to expand production and sales volume, reduce product manufacturing cost, provide a good foundation to reduce the use cost, and need policy support to enhance the use attraction.

\section{A. Demonstrating the application of FECVs}

\section{1) Construction of FECV demonstration operation area}

Taking Luodai Ancient Town as the core, focusing on public transportation, logistics, sanitation and other public areas, we will focus on promoting demonstration operation of hydrogen fuel cell commercial vehicles and special vehicles; with taxis, shared vehicles and government official vehicles as the starting point, we will explore and carry out demonstration operation of hydrogen fuel cell passenger vehicles; accelerate the construction of hydrogenation infrastructure, and build a well-known domestic FECV operation camp demonstration area.

\section{2) Increasing the promotion of FECVs}

Adhere to the market-oriented way to drive industrial development, focus on promoting demonstration operation of FECVs in public service fields such as public transport, sanitation, logistics and distribution, and strive to make the proportion of hydrogen fuel bus to new vehicles no less than $30 \%$ and that of hydrogen fuel sanitation vehicle to new vehicles no less than $20 \%$ by 2022 . With reference to the hydrogen fuel cell commuter mode in Shenzhen, give full play to the characteristics of the industrial park in our district, carry out the hydrogen fuel cell commuter pilot, focus on supporting
Zhongzhi new energy, FAW Toyota and other enterprises to carry out the operation of hydrogen fuel cell commercial vehicles (commuter buses for employees) in the park, and form replicable promotion experience.

\section{3) The pilot of driverless FECVs}

Focus on the industrial trends of NEXO hydrogen fuel cell SUV and SAIC Maxus, which are developing and equipped with the driverless system, and release the fcv80 with the technology of hydrogen fuel cell + driverless, aiming at the cutting-edge technology of driverless and hydrogen fuel cell, and carry out the test operation of driverless + hydrogen powered vehicles relying on the China Germany intelligent network automobile test base. Focus on supporting the China Germany intelligent network vehicle test base to accelerate the creation of application scenarios to meet the needs of industrial integration, innovation and development, and layout FECV test scenarios.

\section{B. Improving the use environment of FECVs}

With the demonstration operation area of FECVs as the key area, and with the goal of meeting the operation demand of FECVs, accelerate the construction of hydrogenation stations, and strive to build more than 20 hydrogenation stations by 2023. Focus on supporting energy enterprises such as PetroChina Kunlun Gas Co., Ltd. and PetroChina Refined Oil Co., Ltd. to build hydrogenation stations with daily hydrogenation capacity of no less than $500 \mathrm{~kg}$ in Nansi road of Economic Development Zone, China France ecological park, North Development Zone of Chengdu Economic Development Zone, etc. in combination with the actual operation of FECV lines.

The pilot projects of LNG and CNG hydrogen stations to be reconstructed (expanded) and hydrogen stations to be reconstructed (expanded) and existing gas stations to be reconstructed (expanded) were launched. In key areas such as China France ecological park, some gas stations and gas stations with hydrogen storage and transportation conditions were selected for the pilot projects. Focus on supporting energy enterprises such as PetroChina Kunlun Gas and PetroChina refined oil, and accelerate the reconstruction, construction and expansion of hydrogenation equipment relying on existing gas stations in the region.

We will make use of the surplus hydropower resources to encourage Daduhe Company of the state energy group and Sichuan natural gas investment company to build an 
joint technical research. We will focus on supporting Chengdu Automotive Industry Research Institute (Chengdu Hydrogen Energy Industry Research Institute) to take the lead in setting up a hydrogen fuel cell automobile industry alliance based on the existing Tianfu automobile industry alliance, and actively carry out technological collaborative research, incubation and transformation of scientific and technological achievements, industrial Summit Forum and industrial exchange activities.

\section{SUMMARY}

In the future, the hydrogen fuel cell vehicle industry will usher in rapid development, and the comprehensive use cost of the products needed in the promotion and use of fuel cell vehicles should be better than or close to other vehicle products. After analysis, the research and development cost and manufacturing cost of hydrogen fuel cell vehicles are relatively high, and the large-scale use cost has certain advantages. In this paper, it was proposed that the whole life cycle cost can be effectively reduced by expanding the scale of ownership through demonstration application, increasing product consumption through basic supporting facilities and encouraging industrial development through policy support, so as to promote the rapid and healthy development of Sichuan hydrogen fuel cell automobile industry.

\section{REFERENCES}

[1] Yang Zibin. Development status and industrialization of hydrogen fuel cell vehicles in China [J]. Automotive practical technology, 2019 (16): 31-33. (In Chinese).

[2] Tian Fang, Chen Lin, Geng Zhiyong. Research on the technical route of fuel cell commercial vehicle [J]. Automotive practical technology. 2018 (18): 26-27. (In Chinese)

[3] Li Tuyu, Yu Dali, Zhang Hongshen. Life cycle assessment of pure electric bus and traditional bus based on green [J]. Environmental science research. 2017 (10): 1653-1660. (In Chinese)

[4] Li Shuhua. Life cycle analysis and environmental benefit evaluation of electric vehicles [D]. Jilin University, 2014. (In Chinese)

[5] Yang Ru, Feng Chao, Zhang Yaowei, Ma Xiaoxi, Wu Jie, Chen Yumeng. Life cycle assessment of hybrid vehicles [J]. New energy progress. 2014 (02): 151-156. (In Chinese)

[6] Wang Renjie. Study on the fuel life cycle assessment of energy and environmental impact of electric vehicles and natural gas vehicles [D]. Tsinghua University, 2015. (In Chinese)

[7] Liu Kaihui. Life cycle assessment of BYD E6 pure electric vehicle [D] Fujian Agricultural and Forestry University, 2016. (In Chinese) achievement appraisal, inspection and testing, standard formulation, etc., and coordinate the establishment of industry exchange and cross-border cooperation platform. And carry out 